\title{
PENGARUH BAURAN PROMOSI TERHADAP VOLUME PENJUALAN PADA PABRIK MESIN INDUSTRI KECAMATAN GEGER KABUPATEN MADIUN
}

\author{
Agus Prasetyo \\ Mahasiswa Prodi Pendidikan Ekonomi FPIPS IKIP PGRI Madiun \\ agus_prasetyo90@gmail.com
}

\begin{abstract}
This study aims to determine how the promotion mix at the Plant Engineering Industrial District Geger Madiun, to determine the volume of sales to the Plant Engineering Industrial District Geger Madiun District, as well as to determine whether or not Influence Between the promotional mix Against the volume of sales to the Plant Engineering Industrial District Geger District Madiun. The samples in this research is to use a purposive sampling (samples intended) is the result of five years of production at the Plant Engineering Industrial District Geger Madiun. Collecting data using the method of documentation, interviews and observasi.Dalam analyze data using statistical methods Product Moment to test the hypotheses put forward in the study tested the hypothesis using the test ..TO $\mathrm{r}, \mathrm{F}$ test and t test. The results showed that the promotion mix has an influence on the volume of sales to the Plant Engineering Industrial District Geger Madiun. It is obtained from the correlation test showed that the value rhitung is 0.8476 while rtabel 0.648. In addition Sighit value is 0,000 while Sigprob 0.05. This means that the value rhitung $\geq \operatorname{rtabel}(0.8476 \geq 0.648)$ or $\leq$ Sighit Sigprob $(0,000 \leq 0.05)$. On the basis of the correlation test, we can conclude $\mathrm{HO}$ is rejected, it means that there is a connection with the promotion mix sales volumes in the "Plant Engineering Industry" Kecamatan Geger Madiun.
\end{abstract}

Keywords: Promotion Mix , Volume of Sales

\begin{abstract}
Abstrak. Penelitian ini bertujuan untuk mengetahui bagaimana bauran promosi pada Pabrik Mesin Industri Kecamatan Geger Kabupaten Madiun, untuk mengetahui volume penjualan pada Pabrik Mesin Industri Kecamatan Geger Kabupaten Madiun, serta untuk mengetahui ada atau tidaknya Pengaruh Antara bauran promosi Terhadap volume penjualan pada Pabrik Mesin Industri Kecamatan Geger Kabupaten Madiun. Penentuan sampel dalam penelitian ini adalah meggunakan purposive sampling (sampel bertujuan) yaitu hasil produksi selama lima tahun pada Pabrik Mesin Industri Kecamatan Geger Kabupaten Madiun. Pengumpulan data menggunakan metode dokumentasi, wawancara dan observasi.Dalam menganalisis data menggunakan metode statistik Product Moment untuk menguji hipotesis yang dikemukakan dalam penelitian ini.Untuk menguji hipotesis menggunakan uji $\mathrm{r}$, uji $\mathrm{F}$ dan uji t. Hasil penelitian menunjukan bahwa bauran promosi mempunyai pengaruh terhadap volume penjualan pada Pabrik Mesin Industri Kecamatan Geger Kabupaten Madiun. Hal ini diperoleh dari uji korelasi yang menunjukkan bahwa besarnya nilai $r_{\text {hitung }}$ adalah 0,8476 sedangkan $r_{\text {tabel }}$ 0,648. Selain itu nilai $\operatorname{Sig}_{\text {hit }}$ adalah 0,000 sedangkan Sig $_{\text {prob }}$ 0,05. Hal ini berarti bahwa nilai $r_{\text {hitung }} \geq r_{\text {tabel }}(0,8476 \geq 0,648)$ atau $\operatorname{Sig}_{\text {hit }} \leq \operatorname{Sig}_{\text {prob }}(0,000 \leq 0,05)$. Atas dasar uji korelasi tersebut dapat disimpulkan $\mathrm{H}_{0}$ ditolak, artinya ada hubungan bauran promosi dengan volume penjualan pada "Pabrik Mesin Industri” Kecamatan Geger Kabupaten Madiun.
\end{abstract}

Kata kunci: Bauran Promosi, Volume Penjualan. 


\section{PENDAHULUAN}

Perekonomian Indonesia telah memasuki era globalisasi. Kemajuan teknologi yang semakin pesat dan adanyaperdagangan bebas memungkinkan semakin terbukanya persainganantar perusahaan. Untuk menghadapi persaingan yang sangat ketat, maka perusahaan tumbuh dan berkembang perlu memperhatikan efektifitas dan efisiensi dalam pendayagunaan sumber daya yang dimilikinya. Untuk mencapai tujuan yang ditetapkan perusahaan tersebut. Keberhasilan suatu perusahaan tercapai, salah satunya karena perusahaan mempunyai strategi yang jitu dan andal serta dapat diimplementasikan dengan tepat pemasarannya.

Pemilihan media promosi yang tepat dan akurat dapat menentukan keberhasilan suatu perusahaan dalam memasarkan produknya. Promosi memerlukan lebih daripada sekedar memperkenalkan keunggulankeunggulan produk, dan harga yang menarik, serta membuatnya dapat terjangkau, akan tetapi kegiatan promosi dimaksudkan untuk dapat melakukan komunikasi dengan konsumen, memperkenalkan, membujuk, mempengaruhi dan mendorong konsumen untuk membeli produk yang ditawarkan serta dapat juga digunakan untuk membangun citra perusahaan dimata konsumen.

Perusahaan-perusahaan juga harus berkomunikasi dengan pihakpihak yang berkepentingan sekarang dan yang akan datang, serta masyarakat umum. Penggunaan media pemasaran maupun media promosi lainnya sama-sama penting.
Salah satu cara yang dilakukan perusahaan agar mampu berkomunikasi dengan konsumen adalah dengan periklanan atau advertising yaitu "semua bentuk terbayar atas presentasi nonribadi dan promosi ide, barang atau jasa oleh sponsor yang jelas".(Kotler, 2009:202).

Volume penjualan merupakan hasil akhir yang di capai perusahaan dari penjualan produk yang dilakukan oleh perusahaan. Volume penjualan di hitung berdasarkan target yang di asumsikan dengan realisasi yang di capai. Dari pengertian di atas maka dapat di simpulkan bahwa volume penjualan merupakan suatu tingkatan keberhasilan penjualan produk yang dinilai menurut satuan mata uang berdasarkan hasil usaha yang dilaksanakan. Dari volume penjualan tersebut suatu perusahaan dapat mengukur tingkat keberhasilan perusahaan tersebut dalam memasarkan produknya.

"Promosi adalah bentuk persuasi langsung melalui penggunaan berbagai insentif yang dapat diatur untuk merangsang pembelian produk dengan segera dan/atau meningkatkan jumlah barang yang dibeli pelanggan" (Fandy Tjiptono, 2008: 229).

Promosi merupakan kegiatan yang ditujukan untuk mempengaruhi konsumen agar mereka dapat menjadi kenal akan produk yang ditawarkan oleh perusahaan kepada mereka dan kemudian mereka menjadi senang lalu membeli produk tersebut.

Hal ini dipertegas Zimmerer dalam Freddy Rangkuti, 2009: 50) menyatakan "promosi adalah segala 
macam bentuk komunikasi persuasi yang dirancang untuk mengimformasikan pelanggan tentang produk atau jasa dan untuk memengaruhi mereka agar membeli barang atau jasa tersebut yang mencakup publisitas, penjualan perorangan dan periklanan".

Menurut J,Stanton ( dalam Swastha, 2002: 238). "Promotion Mix adalah kombinasi strategi yang paling baik dari variabel-variabel periklanan, personal selling, dan alat promosi yang lain, yang semuanya direncanakan untuk mencapai tujuan program penjualan".

Dari berbagai pendapat di atas dapat disimpulkan bahwa bauran promosi merupakan gabungan dari berbagai jenis promosi yang dilakukan perusahaan untuk produkproduk yang di produksi agar mampu mencapai program penjualan yang di inginkan.

Menurut Basu Swastha (2008: 350) "Periklanan merupakan bentuk presentasi dan promosi non pribadi tentang ide, barang, dan jasa yang dibayar oeleh sponsor tertentu".

Sedangkan menurut Fraddy Rangkuti (2009: 23) "periklanan adalah komunikasi non individu dengan sejumlah biaya, melalui berbagai media yang dilakukan oleh perusahaan, lembaga nirlaba serta individu".

Iklan adalah bentuk komunikasi tidak langsung, yang didasari pada informasi tentang keunggulan suatu produk, yang disusun sedemikian rupa sehingga menimbulkan rasa menyenangkan yang akan mengubah pikiran seseorang untuk melakukan pembelian", Fandi Tjiptono (2008: 226).
Sedangkan menurut Sofjan Assauri (2011:265) "Advertensi atau iklan merupakan suatu bentuk penyajian dan promosi dari gagasan, barang, atau jasa yang dibiayai oleh suatu sponsor tertentu yang bersifat nonpersonal".

Jadi Periklanan dapat diartikan sebagai bentuk peresentasi nonpersonal yang dibayar oleh sponsor untuk mempresentasikan gagasan atau ide promosi dari barang atau jasa tertentu. Pada iklan biasanya ditampilkan organisasi yang mensponsorinya. Dalam praktiknya, iklan dianggap sebagai manajemen citra yang bertujuan menciptakan dan memelihara cipta dan makna dalam benak konsumendan tujuan akhir dalam iklan adalah mempengaruhi perilaku pembelian konsumen.

"Personal selling adalah komunikasi langsung (tatap muka) antara penjual dan calon pembeli untuk memperkenalkan suatu produk kepada calon pelanggan dan membentuk pemahaman pelanggan terhadap produk sehingga mereka kemudian akan mencoba dan membelinya"(Fandi Tjiptono ,2008: 224).

Sedangkan menurut Freddy Rangkuti (2009: 26) "Penjualan perseorangan adalah interaksi antar individu, saling bertemu muka yang ditunjukan untuk menciptakan, memperbaiki, menguasai atau mempertahankan hubungan pertukaran yang saling menguntungkan dengan pihak lain".

Hal ini dipertegas oleh pendapat Basu Swastha (2008: 350) yang menyatakan bahwa "personal selling adalah presentasi lisan dalam suatu percakapan dengan satu calon 
pembeli yang ditujukan untuk menciptakan penjualan".

Dari beberapa pendapat para ahli maka penulis menyimpulkan penjualan perseorangan merupakan kegiatan promosi yang dilakukan dengan melukukan pendekatan secara individu kepada calon pembeli untuk menciptakan penjualan.

Menurut Freddy Rangkuti (2009: 27) "Publisitas merupakan usaha untuk merangsang permintaanterhadap suatu produk secara nonpersonal dengan membuat berita yang bersifat komersial tentang produk tersebut dalam media cetak atau tidak, maupun hasil wawancara yang disiarkan dalam media terebut".

Kotler dan Amstrong (dalam Rangkuti, 2009: 27) "menjelaskan bahwa publisitas adalah aktivtas untuk mempromosikan perusahaan atau produknya dengan membuat berita mengenai subjek itu tanpa dibayar oleh sponsor".

Promosi penjualan adalah salah satu kegiatan promosi untuk melakukan rangsangan kepada konsumen untuk melakukan pembelian. Menurut Kotler \& Amstrong (dalam Rangkuti, 2009: 28) "promosi penjualan adalah insentive jangka pendek untuk mendorong pembelian atau penjualan dari produk atau jasa".

Sedangkan Promosi Penjualan menurut Basu Swastha (2008: 353), "merupakan kegiatan promosi selain periklanan, personal selling maupun publisitas.

Jadi, promosi penjualan merupakan kegiatan promosi yang dapat mendorong pembelian oleh konsumen, dan yang dapat meningkatkan efektivitas para distributor dan retailer dengan mengadakan pameran, display, eksibisi, peragaan dan berbagai kegiatan penjualan lainya, yang dilakukan sewaktu-waktu dan tidak rutin. Dalam promosi penjualan perusahaan menggunakan alat-alat tertentu seperti hadiah, paket harga, peragaan, pameran, demonstrasi dan contoh barang.

$\begin{array}{cc}\text { Sofjan Assauri } & \text { (2010:23) } \\ \text { bahwa kegiatan } & \text { penjualan }\end{array}$
merupakan kegiatan pelengkap atau suplemen dari pembelian, untuk memungkinkan terjadinya transaksi. Jadi kegiatan pembelian dan penjualan merupakan satu kesatuan untuk dapat terlaksananya transfer hak atau transaksi. Oleh karena itu, kegiatan penjualan seperti halnya kegiatan pembelian, terdiri dari serangkaian kegiatan yang meliputi penciptaan permintaan (demand), menemukan si pembeli, negosiasi harga, dan syarat-syarat pembayaran.

Hal ini dipertegas oleh pendapat Freddy Rangkuti (2009: 57) menyatakan bahwa "volume penjualan adalah pencapaian penjualan yang dinyatakan secara kuantitatif dari segi fisik atau volume atau unit suatu produk. Volume penjualan merupakan suatu yang menandakan naik turunya penjualan dan dapat dinyatakan dalam bentuk unit, kilo, ton atau liter".

Berdasarkan definisi di atas dapat ditarik kesimpulan bahwa volume penjualan adalah jumlah penjualan yang berhasil dilakukan perusahaan yang dinyatakan dalam bentuk angka-angka atau unit produk yang mampu terjual kepada pembeli dalam kurun waktu tertentu. Kenaikan volume penjualan 
produk/jasa berarti kenaikan dari segi pendapatan perusahaan.

Adapun faktor-faktor yang mempengaruhi volume penjualan menurut Kotler (2009:55) antara lain adalah :

1) Harga jual.

Faktor harga jual merupakan hal-hal yang sangat penting dan mempengaruhi penjualan atas barang atau jasa yang dihasilkan. Apakah barang atau jasa yang ditawarkan oleh perusahaan dapat dijangkau oleh konsumen sasaran.

2) Produk.

Produk salah satu faktor yang mempengaruhi tingkat volume penjualan sebagai barang atau jasa yang ditawarkan oleh perusahaan apakah sesuai dengan tingkat kebutuhan para konsumen.

3) Promosi.

Promosi adalah aktivitasaktivitas sebuah perusahaan yang dirancang untuk memberikan informasi-informasi membujuk pihaklain tentang perusahaan yang bersangkutan dan barang-barang serta jasajasa yang ditawarkan.

4) Saluran Distribusi.

Merupakan

perusahaan

aktivitas

menyampaikan

untuk

menyalurkan barang yang ditawarkan oleh perusahaan kepada konsumen yang diujinya.

5) Mutu.

Mutu dan kualitas barnag merupakan salah satu faktor yang mempengaruhi volume penjualan. Dengan mutu yang baik maka konsumen akan tetap loyal terhadap produk dari perusahaan tesebut, begitu pula sebaliknya apabila mutu produk yang ditawarkan tidak bagus maka konsumen akan berpaling kepada produk lain.

\section{METODE PENELITIAN}

Penelitian dilakukan pada perusahaan "Pabrik Mesin Industri" di Kecamatan Geger Kabupaten Madiun.Alasanpemilihan tempat tersebut dikarenakan perusahaan "Pabrik Mesin Industri" merupakan perusahaan sedang berkembang dan merupakan satu-satunya perusahaan yang mampu menyediakan mesinmesin industri dan pertanian di wilayah Madiun selatan yang sangat diminati oleh para pengusaha mikro dan menengah guna meningkatkan produksinya.

"Desain penelitian untuk membantu penelitian dalam mengalokasikan sumber daya yang terbatas dengan menempatkan pilihan penting dalam metodologi" (Philips dalam Juliansyah Noor, 2011: 108). Sedangkan menurut (Karlinger dalam Juliansyah Noor, 2011: 108), "desain penelitian diklasifikasikan sebagai sebagai rencana dan struktur investigasi yang dibuat sedemikian rupa sehingga diperoleh jawaban atas pertanyaan penelitian".

Dalam penelitian ini menggunakan desain penelitian konklusif. menurut Juliansyah Noor (2011:110), "penelitian konklusif yaitu jenis penelitian yang bertujuan untuk menguji hipotesis. Penelitian konklusif didesain untuk membantu mengambil keputusan dalam menentukan, mengevaluasi dan memilih alternatif terbaik dalam memecahkan suatu masalah". Alasan 
penggunaan desain penelitian konklusifdisesuikan dengan tujuan penelitian yang menguji hipotesis dan menguji hubungan.

Jenis penelitian ini adalah penelitian kuantitatif. Sugiyono (2007: 8) menyatakan "penelitian kuantitatif merupakan metode penelitian yang berlandaskan pada filsafat positivisme, digunakan untuk meneliti pada populasi atau sampel tertentu, pengumpulan data menggunakan instrument penelitian, analisis data bersifat kuantitatif/statistik, dengan tujuan untuk menguji hipotesis yang telah ditetapkan". Dengan menggunakan metode ini, maka dapat diketahui ada tidaknya pengaruh bauranpromosi terhadap volume penjualan.

Sehubungan dengan penelitian ini peneliti menentukan dua variabel yaitu variabel bebas (X) adalah bauran promosi dan variabel terikat (Y) adalah volume penjualan.

Penelitian ini dilakukan untuk mengetahui apakah bauran promosi (X) berpengaruh terhadap volume penjualan (Y) pada pabrik mesin industri Kecamatan Geger Kabupaten Madiun.

\begin{tabular}{|c|c|}
\hline $\begin{array}{l}\text { Bauran } \\
\text { Promosi } \\
\quad(\mathrm{X})\end{array}$ & $\begin{array}{l}\text { Volume } \\
\text { Penjualan } \\
\text { (Y) }\end{array}$ \\
\hline
\end{tabular}

Gambar Rancangan Penelitian

Adapun populasi dalam penelitian ini adalah "Pabrik Mesin Industri" yang terletak di Kecamatan Geger Kabupaten Madiun.Adapun sampel dalam penelitian ini adalah bauran promosi dan volume penjualan "Pabrik Mesin Industri" yang terletak di Kecamatan Geger
Kabupaten Madiun. Selama lima tahun yang di hitung setiap triwulan atau tiga bulan, yaitu mulai tahun 2009 hingga tahun 2014.

"Teknik sampel adalah metode mengumpulkan informasi (data) terhadap sebagian anggota populasi. Sampel harus diambil representative, artinya mewakili seluruh populasi oleh karenanya pemilihan sampel harus di usahakan sedemikian rupa sehimgga memberikan gambaran seluruh populasi". (Gabriel Amin Silalahi, 2003:65)

Adapun teknik pengambilan sampel dalam penelitian ini adalah menggunakan Purposive Sampling (Sampel Bertujuan). Suharsimi Arikunto (2010: 183) memberikan pendapat bahwa "sampel bertujuan dilakukan dengan cara mengambil subjek bukan didasarkan atas strata, random atau daerah tetapi didasarkan atas adanya tujuan tertentu".

\section{Teknik Pengumpulan Data}

Teknik pengumpulan data dalam penelitian adalah:

1) Metode dokumentasi.

Suharsimi Arikunto (2010: 201) menyatakan "dokumentasi adalah mencari data mengenai halhal atau variabel yang berupa catatan, transkrip, buku, surat kabar, majalah, prasasti, notulen rapat, lengger, agenda dan sebagainya".

Metode ini dipergunakan untuk memperoleh data yang menunjang data penelitian seperti data bauran promosi dan data volume penjualan yang dilakukan perusahaan Pabrik Mesin Industri. 
2) Metode wawancara

"Wawancara yaitu teknik pengumpulan data yang menggunakan pertanyaan secara lisan kepada subjek penelitian" (Gabriel Amin, 2003: 81).Sedangkan menurut Suharsimi Arikunto (2010: 198) "wawancara atau kuesioner lisan, adalah sebuah dialog yang dilakukan oleh pewawancara (interviewer) untuk memperoleh informasi dari terwawancara.Dalam penelitian ini metode wawancara yang digunakan adalah metode wawancara bebas terpimpin, yaitu kombinasi antara wawancara bebas dan wawancara terpimpin.

\section{3) Observasi}

Menurut Suharsimi Arikunto (2010: 199) "observasi atau yang sering disebut pula dengan pengamatan, meliputi kegiatan pemuatan perhatian terhadap suatu objek dengan menggunakan seluruh alat indra".

Dalam penelitian ini observasi yang dilakukan oleh peneliti adalah kegiatan mengamati proses kegiatan bauran promosi yang dilakukan perusahaan "Pabrik Mesin Industri" hingga proses penjualan.

Adapun Intrumen yang digunakan dalam penelitian ini adalah berupa pedoman wawancara, berupa pertanyan - pertanyan yang berkaitan dengan bauran promosi dan volume penjualan kepada pemilik "Pabrik Mesin Industri" Kecamatan Geger Kabupaten Madiun.

\section{Teknik Analisis Data}

Dalam menganalisis data menggunakan analisis linear sederhana.Di mana hanya ada satu variabel $X$ yang mempengaruhi satu variabel Y.

Keterangan untuk masingmasing adalah sebagai berikut:

1. Uji Korelasi

Analisis korelasi product moment berguna untuk menentukan suatu besaran yang menyatakan bagaimana kuat hubungan suatu variabel dengan variabel lain (Usman Rianse dan Abdi, 2012 : 167).

2. Uji F

"Uji F yaitu alat analisis data yang digunakan untuk mengetahui apakah semua variabel bebas secara bersama-sama mempunyai pengaruh yang signifikan terhadap variabel terikatnya (Gabriel Amin Silalahi, 2003: 86)".

\section{Uji T}

Menurut Grabiel Amin Silahi (2003: 86), "uji t yaitu alat analisis untuk mengetahui apakah variabel bebas secara individual mempunyai pengaruh yang signifikan terhadap variabel terikat".

\section{HASIL PENELITIAN}

Variabel bauran promosi dapat dideskripsikan dengan jumlah data (N) sebanyak 20 mempunyai deskripsi data sebagai berikut: (a) jumlah skor total sebesar 11533; (b) nilai rata-rata hitung (mean) sebesar 576.65; (c) median sebesar 600.00; (d) modus sebesar 600; (e) standar deviasi sebesar300.275; (f) nilai minimum sebesar 133; (g) nilai maximum sebesar 1300 . 
Variabel volume penjualan dapat dideskripsikan dengan jumlah data (N) sebanyak 20 mempunyai deskripsi data sebagai berikut: (a) jumlah skor total sebesar 4020600; (b) nilai rata-rata hitung (mean) sebesar 2.01E5; (c) median sebesar2.12E5; (d) modus sebesar $94500^{\mathrm{a}}$; (e) standar deviasi sebesar 6.466E4; (f) nilai minimum sebesar 94500; (g) nilai maximum sebesar 295500.

\section{Hasil Uji Regresi}

Dari hasil uji regersi linier dapat diperoleh persamaan garis regresi dinyatakan dengan $\mathrm{Y}=\mathrm{a}+$ $\mathrm{bX}$, diperoleh hasil $\mathrm{Y}=95778.72+$ 182.52X, artinya apabila bauran promosi ditingkatkan dengan $1 \%$ akan terjadi kenaikan volume penjualan sebanyak $182.52 \%$, apabila faktor yang lainnya dianggap tetap.

\section{Hasil Uji Korelasi}

Berdasarkan uji korelasi didapat besarnya nilai $r_{\text {hitung }}$ adalah 0,8476 sedangkan $r_{\text {tabel }} 0,648$. Selain itu nilai Sighit adalah 0,000 sedangkan $\mathrm{Sig}_{\text {prob }} 0,05$. Hal ini berarti bahwa nilai $r_{\text {hitung }} \geq r_{\text {tabel }}$ $(0,8476 \geq 0,648)$ atau $\operatorname{Sig}_{\text {hit }} \leq \operatorname{Sig}_{\text {prob }}$ $(0,000 \leq 0,05)$. Atas dasar uji korelasi tersebut dapat disimpulkan $\mathrm{H}_{0}$ ditolak, artinya ada hubungan bauran promosi dengan volume penjualan pada "Pabrik Mesin Industri" Kecamatan Geger Kabupaten Madiun.

Dilain pihak dalam uji determinasi yang diperoleh nilai $r^{2}$ atau koefisien determinasi yang digunakan untuk mengetahui seberapa besar prosentase sumbangan bauran promosi terhadap volume penjualan.Berdasarkan perhitungan tersebut di atas dapat diketahui nilai $\mathrm{r}^{2}$ adalah 0,767. Jadi sumbangan pengaruh dari bauran promosi terhadap volume penjualan yaitu $76,7 \%$ sedangkan sisanya sebesar 23,3\% dipengaruhi oleh faktor lain.

\section{Hasil Uji F/Fisher}

Berdasarkan uji fisher didapat bahwa besarnya nilai $F_{\text {hitung }}$ adalah 45,955 sedangkan $F_{\text {tabel }}$ sebesar 4,414di lain pihak besarnya $\mathrm{Sig}_{\text {hit }}$ adalah 0,000 sedangkan Sig prob 0,05. Hal ini berarti bahwa nilai $F_{\text {hitung }} \geq$ $F_{\text {tabel }}(45,955 \geq 4,414)$ atau Sighit $\leq$ Sig $_{\text {prob }}(0,000 \leq 0,05)$. Atas dasartersebut dapat disimpulkan $\mathrm{H}_{0}$ ditolak, artinya ada pengaruh bauran promosi terhadap volume penjualan pada"Pabrik Mesin Industri" Kecamatan Geger Kabupaten Madiun.

\section{Hasil Uji t}

Berdasarkan uji $t$ dapat diketahui bahwa nilai $t_{\text {hitung }}$ adalah 6,779sedangkan $t_{\text {tabel }}$ sebesar $1,734 \mathrm{di}$ lain pihak nilai $\mathrm{Sig}_{\text {hit }}$ adalah 0,000 sedangkan $\mathrm{Sig}_{\text {prob }} 0,05$. Hal ini berarti bahwa nilai $t_{\text {hitung }} \geq t_{\text {tabel }}$ $(6,779 \geq 1,734)$ atau $\operatorname{Sig}_{\text {hit }} \leq \operatorname{Sig}_{\text {prob }}$ $(0,000 \leq 0,05)$. Atas dasar uji $t$ tersebut dapat disimpulkan $\mathrm{H}_{0}$ ditolak, artinya ada beda pengaruh bauran promosi terhadap volume penjualan pada "Pabrik Mesin Industri" Kecamatan Geger Kabupaten Madiun.

Dari pengujian hipotesis regresi linier sederhana, uji korelasi, uji f, uji $\mathrm{t}$, dengan data $\mathrm{N}$ sebanyak 20 dapat diambil keputusan bahwa ada pengaruh yang signifikan antara bauran promosi terhadap volume 
penjualan pada Pabrik Mesin Industri Kecamatan Geger Kabupaten Madiun.

\section{PENUTUP}

\section{Simpulan}

Berdasarkan hasil analisis data dan pembahasan pada bab sebelumnya dapat disimpulkan sebagai berikut:

1) Bauran promosi pada "Pabrik Mesin Industri" Kecamatan Geger Kabupaten Madiun adalah baik.Hal ini dapat dilihat dari hasil analisis bauran promosi diatas dapat diketahui dari 20 triwulan yang berada di atas nilai rata-rata $\geq 576,65$ sebanyak 12 triwulan atausebanyak $60 \%$. Sedangkan nilai dibawah rata-rata sebanyak 8 triwulan atau $40 \%$. Hal ini disimpulkan bahwa bauran promosi di "Pabrik Mesin Industri" Kecamatan Geger Kabupaten Madiun adalah baik karena 12 triwulan atau $60 \%$ diatas rata-rata.

2) Volume penjualan pada "Pabrik Mesin Industri" Kecamatan Geger Kabupaten Madiun adalah baik. Hal ini dapat dilihat dari hasil analisis volume penjualan dapat diketahui dari 20 triwulan mempunyai nilai di atas rata-rata $\geq$ 2.01E5 sebanyak 11triwulan atau55 \%. Sedangkan nilai dibawah rata-rata sebanyak 9 triwulan atau $45 \%$. Hal ini disimpulkan bahwa volume penjualan di "Pabrik Mesin Industri" Kecamatan Geger Kabupaten Madiun adalah baik karena 11 triwulan atau $55 \%$ diatas rata-rata.

3) Bauran Promosi mempunyai pengaruh terhadap volume penjualan pada "Pabrik Mesin Industri" Kecamatan Geger Kabupaten Madiun. Terbukti dari hasil analisis regresi yang memuat uji korelasi, uji F, dan uji t.

\section{Saran}

1. Bagi Perusahaan

Karena Bauran promosi terbukti mempunyai pengaruh terhadap volume penjualan, maka pada "Pabrik Mesin Industri" Kecamatan Geger Kabupaten Madiun harus mampu melakukan bauran promosi dengan baik dan sesuai dengan pangsa pasar yang dibutuhkan pangsa pasar.

Dari berbagai bauran promosi yang digunakan, personal selling dan periklanan mempunyai kontribusi yang cukup besar terhadap peningkatan volume penjualan. Maka kedua promosi tersebut harus terus di tingkatkan tanpa mengesampingkan teknikteknik promosi yang lain, pemilihan kombinasi promosi yang tepat dan akurat akan mampu berdampak positif terhadap meningkatnya volume penjualan perusahaan.

2. Bagi Penelitian Mendatang

Bagi penelitian yang akan datang sebaiknya mengadakan pengembangan penelitian ini dengan menggunakan variabel bebas selain bauran promosi atau menambah variabel bebas yang ingin diteliti. Karena selain promosi masih banyak faktor yang mempengaruhi volume penjualan dalam home indsutri.

3. Bagi Ilmu Pengetahuan

Bagi ilmu pengetahuan diharapkan skripsi ini dapat menambah khazanah keilmuan 
tentang bauran promosi dan volume penjualan serta sebagai bahan referensi dalam ilmu pendidikan khususnya tentang bauran peomosi dan volume penjualan dan dapat dikembangkan lebih kanjut terhadap penelitian yang sejenis.

\section{DAFTAR PUSTAKA}

Basu Swastha dan Irawan. 2008. Manajemen Pemasaran Modern. Edisi Ketigabelas. Yogyakarta: Liberty.

Boyd, Walker dan Larreche. 2000. Manajemen Pemasaran. Edisi Kedua. Yogyakarta: Erlangga.

Buchari Alma.2013. Manajaemen Pemasaran dan Pemasaran Jasa. Bandung: Alfabeta.

Freddy Rangkuti. 2009. Strategi promosi yang kreatif dan Analisis Kasus Integrated Marketing Comunications. Jakarta:PT. Gramedia Pustaka Utama.

Fandy Tjiptono. 2008. Strategi Pemasaran. Yogyakarta: CV.Andi Offset.

Philip Kotler. 2009.Manajemen Pemasaran. Yogyakarta: Erlangga.

Suharsimi Arikunto. 2002. Prosedur Penelitian Suatu Pendekatan Praktik. Jakarta: PT. Rineka Cipta.
Gabriel Amin Silalahi. 2003. Metode Penelitian Studi Kasus. Sidoarjo: Citra Media.

Sukardi. 2011. Metode Penelitian Pendidikan. Jakarta: PT. Bumi Aksara.

Sugiyono. 2010. Metode Penelitian Pendidikan.Bandung: Alfabeta.

Juliansyah Noor. 2011. Metode Penelitian. Jakarta: Kencana Prenada Media Group.

Husaini Usman. 2004. Metodologi Penelitian Sosial. Jakarta: PT Bumi Aksara.

Husein Umar. 2011. Metode Penelitian Untuk Skripsi Dan Tesis Bisnis. Jakarta: Rajawali Pers.

Usman Rianse dan Abdi. 2012. Metodologi Penelitian Sosial Dan Ekonomi Teori dan Aplikasi. Bandung: Alfabeta.

Iqbal Hasan. 2004. Analisis Data dan Penelitian Dengan Statistik. Jakarta: PT Bumi Aksara.

Nana Syaodih Sukmadinata. 2011. Metode Penelitian Pendidikan. Bandung: PT Remaja Rosdakarya.

Soeratno dan Lincolin Arsyad. Metodologi Penelitian Untuk Ekonomi Dan Bisnis. Yogyakarta: Unit Penerbit dan Percetakan. 